\title{
Parents' Willingness to Allow Their Unaccompanied Children to Use Emerging and Future Travel Modes
}

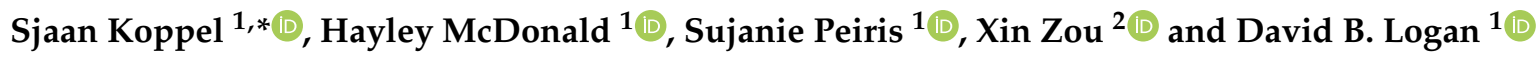 \\ 1 Monash University Accident Research Centre, Monash University, Clayton, VIC 3800, Australia; \\ hayley.mcdonald@monash.edu (H.M.); sujanie.peiris@monash.edu (S.P.); david.logan@monash.edu (D.B.L.) \\ 2 Monash Institute of Transport Studies, Monash University, Clayton, VIC 3800, Australia; xin.zou@monash.edu \\ * Correspondence: sjaan.koppel@monash.edu; Tel.: +61-3-9905-4739
}

check for updates

Citation: Koppel, S.; McDonald, H.; Peiris, S.; Zou, X.; Logan, D.B. Parents' Willingness to Allow Their Unaccompanied Children to Use Emerging and Future Travel Modes. Sustainability 2022, 14, 1585. https:// doi.org/10.3390/su14031585

Academic Editor: Marilisa Botte

Received: 15 December 2021

Accepted: 27 January 2022

Published: 29 January 2022

Publisher's Note: MDPI stays neutral with regard to jurisdictional claims in published maps and institutional affiliations.

Copyright: (C) 2022 by the authors. Licensee MDPI, Basel, Switzerland. This article is an open access article distributed under the terms and conditions of the Creative Commons Attribution (CC BY) license (https:// creativecommons.org/licenses/by/ $4.0 /)$.

\begin{abstract}
This study investigated parents' willingness to allow their unaccompanied child(ren) to use emerging and future travel modes (e.g., rideshare vehicles and automated vehicles). An online survey was completed by 631 Australian respondents $(\mathrm{M}=39.2$ years, $\mathrm{SD}=10.5$ years, Male: $36.6 \%)$ who reported that they currently lived with one or more children (17 or below). Approximately one-third $(37.9 \%)$ of the respondents reported a willingness to allow their child to use a rideshare vehicle alone and more than half of the respondents (57.2\%) reported a willingness to allow their child to use an automated vehicle alone. Respondents who expressed willingness to allow their child to use a rideshare vehicle alone were more likely to express a willingness to use an automated vehicle alone $(79.1 \%)$ compared to respondents who were unwilling to use a rideshare vehicle $(43.9 \%)$, $\chi^{2}(1)=75.158, p<0.001$, Phi $=0.345$. Two separate logistic regression models revealed key similarities and differences related to respondents' willingness to allow their unaccompanied child to use both transport modes. Respondents' willingness to allow their unaccompanied child to use a rideshare vehicle was significantly related to their previous use of a rideshare vehicle with their child, having an optimistic view of technology, annual mileage, their aberrant driving behaviours, and their desire for route-control and assurance features within the rideshare vehicle, $\chi^{2}(7)=159.594, p<0.001$. Respondents' willingness to allow their child to use an automated vehicle alone was significantly related to awareness of automated vehicles, education level, positive views towards technology, seeing technology to be innovative, and requirements for route control features within the automated vehicle, $\chi^{2}(6)=113.325, p<0.001$. Despite the potential for emerging or future travel modes to provide additional personal transportation options, these results suggest that Australian parents are unwilling to allow their unaccompanied child to use these modes of transport. These findings will have significant implications for transport planning, particularly in growing communities where pressures on parents to transport their child(ren) to activities and events with minimal adult supervision is increasing.
\end{abstract}

Keywords: rideshare services; automated vehicles; child occupants; road safety

\section{Introduction}

There is an increasing global emphasis on emerging and future travel modes for providing safe, affordable, accessible, and sustainable transportation [1], especially for those who are vulnerable and unable to drive, or for those who are unable to obtain a driver's licence [2]. Children are such a sub-population, dependent on parents for their transportation. Consequently, parents are under increased pressure to provide a means of transportation for their children, despite significant time and work demands. At present, the availability of rideshare services to transport children and in future, the availably of automated vehicles to transport their unaccompanied children, could provide a mechanism by which children are able to travel independently, easing the pressures on parents. Consequently, the current study aimed to identify the factors associated with 
parents' willingness to use emerging and future transport modes (i.e., rideshare vehicles and automated vehicles) to transport their children alone. Understanding the factors that may influence parents' decision-making to use these transportation modes is essential to guiding the development of policies and strategies that encourage their use.

\section{Related Work}

The decision to use either a rideshare or automated vehicle to transport an unaccompanied child, like all methods of transportation, comes with both advantages and disadvantages. Many of these advantages and disadvantages are evident for both rideshare and automated vehicles. However, others are unique to either rideshare or to automated vehicles. This is primarily because rideshare is a transportation method that is already available, whereas transportation using automated vehicles is not yet accessible. The following section explores the advantages and disadvantages of both transportation modes in relation to the four broad areas noted in the introduction for which there is a global emphasis, which, as noted, were that transportation must be safe, affordable, accessible, and sustainable.

Child safety is often considered paramount by parents and guardians, and for minors travelling unaccompanied the appropriate use of a child restraint is one factor which affects this. Koppel et al. [3], in a study of Australian parents travelling with children in rideshare vehicles, noted that rates of use of appropriate restraints were lower (57.3\%), when compared to travelling in a private vehicle $(85.6 \%)$. Other research also supports concerns regarding lower levels of appropriate restraint use by children travelling in rideshare vehicles [4-6]. Concerns also stem from rideshare drivers, who may be pressured to transport inappropriately restrained children [7]. Automated vehicles also present challenges and concerns in relation to child restraints. In a study undertaken by Lee and Mirman [8], which examined parents' perspectives on automated vehicles for enhancing children's mobility, it was noted that parents with children who were relatively young and required a child restraint system had greater concerns about the child travelling in an automated vehicle than parents of older children who only required use of a seatbelt. Thus, it is evident that both rideshare and automated vehicles share common concerns in relation to children being safely restrained.

Rideshare also presents concerns for personal safety and security, given that the service involves transportation with a person unknown to the passenger. Lee et al. [9] sought to examine whether the level of safety a person perceives in travelling in a rideshare vehicle has an impact on their likelihood of choosing to use the service. The results showed that this is indeed the case. If a person feels that travelling in a rideshare vehicle is safe, there is a higher likelihood they will travel in one. Similarly, in a study of older people and their willingness to use rideshare services, one factor that was recognised as being a barrier to use was concern relating to the driver, including fear of becoming a victim of crime, as well as concern about the driver's history, their use of alcohol or drugs and the possibility that they may drive whilst tired [10].

Concerns about personal safety and security also present themselves in relation to automated vehicles. Whilst, as noted above, there may be concerns about the conduct of the driver when travelling in a rideshare vehicle, automated vehicles, despite not having a driver present, are not immune to similar parental concerns. A study undertaken by Lee et al. [11] sought to examine factors that may influence parents' willingness to transport their children in an automated vehicle. It emerged that parents had concerns about a stranger being able to enter the vehicle and cause harm to their child on an unaccompanied trip, as well as the potential risks to their child when they reached their destination and who might be there to offer care to their child. This was consistent with another study that examined parents' willingness to use automated vehicles to transport their children to school. It was found that parents who perceived greater levels of risk were less likely to express willingness to use an automated vehicle for transportation of children [12]. Concerns about children's personal safety were also identified as factors 
influencing uptake of automated vehicles for transporting children by Tremoulet et al. [13]. Similarly, Koppel et al. [14], in a study that examined Australian parents' willingness to use an automated vehicle to transport their unaccompanied children, found that, whilst most participants reported that they would never allow this, they did express that having technology installed in these vehicles, which would enable them to monitor their children and seek assistance if required, might influence their decision.

Passengers using rideshare, or alternatively, parents considering rideshare services to transport their unaccompanied children, have little say on the type of vehicle or the experience and professionalism of the driver operating the vehicle. The incidence of motor vehicle crashes is a significant public health concern, with an average of 1100 people killed per year due to road crashes in Australia in the ten years to 2020 [15]. This can be considered in contrast to automated vehicles, where research shows that automated vehicle technology, such as forward collision and lane departure systems, blind spot monitoring and adaptive headlights, will have the potential to prevent crashes from occurring [16]. As automated vehicle technology becomes more sophisticated, and eventually takes over from humans in the operation of vehicles, the potential to avoid crashes will increase even further, hence enhancing safety for passengers [16,17]. Parents may therefore feel more confident in using automated vehicles to transport their children compared to rideshare services. Perceiving automated vehicles as being safe has been considered predictive of an individual's willingness to embrace automated vehicle technology [18]. It is notable, however, that a study undertaken by Szénási [19] did make the important point that, despite having sophisticated technologies within them, automated vehicles still do not have the capacity to respond to incidents without warning, such as a pedestrian stepping out or a road that has become slippery. Szénási [19] highlighted the potential to use existing crash data built into the programming of automated vehicles to address this issue.

In addition to the issues of safety explored above, affordability of child-friendly transportation modes is likely to be an important factor in the decision-making process. In a study on individuals' willingness to embrace automated vehicles, cost was identified as one of the deciding factors [20]. The purchase and ongoing maintenance of vehicles present a significant cost to individuals. Sperling et al. [21] examined the financial implications associated with owning an automated vehicle. The authors identified that the purchase price of a new (conventional) car, its depreciation over time, registration, insurance, fuel costs and maintenance would be substantially larger than that associated with using an automated vehicle as part of a commercial arrangement. In such a scenario, an individual would not own the vehicle, but use the transportation service(s) when required. Rideshare also sees reduced travel costs [22]; in a study that examined factors that may act as barriers or facilitators to rideshare use amongst older people, $77.6 \%$ of participants agreed with the statement that 'rideshare services are cost effective', with some participants highlighting that rideshare is more cost effective than vehicle ownership [10].

Having access to rideshare services and automated vehicles to transport unaccompanied children is likely to have significant implications. For example, Blyth [23] noted that automated vehicles will provide an opportunity to groups of people who do not have the ability to drive themselves, including children and the elderly. Whilst there has been limited focus on the opportunities for access to transport that both rideshare and automated vehicles present for children, there has been more attention given to the accessibility of these transportation issues for the elderly. Such research provides valuable learning on how accessible rideshare and automated vehicles can be extended to children.

A significant factor that was identified by Bayne et al. [10] in their study on the barriers and facilitators of rideshare for older people was the positives that rideshare presented for independence. Many participants noted that rideshare allowed them to get to places and increased their ability to have social interactions. Older children are likely to benefit from such independence, particularly those who wish to travel to sporting and social gatherings. Freund et al. [24] also considered rideshare for older people. They developed a model which identified four broad categories of factor that may present barriers or facilitators for older 
people to access rideshare: individual factors (e.g., age, gender, physical and mental health); interpersonal factors (e.g., social network); organisational factors (e.g., characteristics of rideshare businesses); community factors (e.g., access to rideshare services), and public policy and the marketplace (e.g., regulations that can provide ease or difficulty in accessing rideshare services). They noted that access to technology may present barriers or facilitate access to services. Whilst there may be differences in the factors that act as barriers and facilitators for children when compared to older people, there are also likely to be many similarities, relating to organisational factors, community factors and public policy and the marketplace.

Understanding of accessibility in relation to automated vehicles is far less clear, given, as noted, that automated vehicles are not readily available for use on public roads at present. Despite this, research has sought to examine factors that may influence their uptake in the future. Several factors have been identified, including concerns around privacy, the likely high purchase price (should individuals choose to own an automated vehicle), and the uncertainty that remains about their impacts on the environment and safety [25]. Spurlock et al. [26] highlighted that ensuring automated vehicles are able to penetrate the market must start with giving access to those who are most interested in them. Thus, it can be suggested that, in the early stages, accessibility will be driven largely by the number of people who are interested, which will have an impact on the number of automated vehicles that enter the market [20]. As automated vehicles move towards being more mainstream in the future, it is likely that we will develop greater understanding of factors that will influence their accessibility.

Sustainability of rideshare and automated vehicles can be considered from multiple perspectives, given the diversity of the term 'sustainable'. In a study undertaken by Williams et al. [27] which focused on the sustainability of automated vehicles, sustainability was considered in relation to environmental, economic, and social impacts. Thus, the following section briefly touches on each of these factors, for both rideshare and automated vehicles. Environmental sustainability is a factor that has become an area of increased concern in recent years, and will no doubt continue to grow. Both rideshare and automated vehicles have been recognised as carrying potential environmental benefits, but there remains uncertainty. For example, Zhang and Zhang [28] highlighted that there is evidence that rideshare reduces vehicle ownership and single-occupant trips, positively impacting the environment. Similarly, Greenblatt and Shaheen [29] also noted that rideshare services appear to reduce vehicle ownership and distance travelled each year, which is likely to have environmental benefits. Ward et al. [30] examined the impacts that the introduction of rideshare services into a geographical area have on several factors, one of which was emissions. They found evidence to suggest that such introductions reduce emissions. Despite this, Jin et al. [31] suggested that the influence of rideshare on emissions remains largely unknown.

In terms of automated vehicles, Polydoropoulou et al. [32] suggested that they are predicted to have a significant impact on reducing emissions. Conversely, Massar et al. [33] undertook a review of literature that considered greenhouse gas emissions and automated vehicles, concluding that there is evidence to suggest that there is uncertainty as to whether automated vehicles will result in increases or decreases in emissions. Ultimately it was concluded that, for automated vehicles to result in a substantial decline in emissions, there would need to be high penetration into the network.

The use of rideshare and automated vehicles to transport unaccompanied children could also have the potential to address important social issues such as traffic congestion. A study undertaken by the Bureau of Infrastructure, Transport and Regional Economics (BITRE) estimated the social costs of traffic congestion to be $\$ 16.5$ million in 2015, predicting that this may rise to $\$ 30$ million by 2030 [34]. There is evidence to suggest that automated vehicles have the potential to reduce the costs associated with traffic congestion [16] and have an influence on effects pertaining to economic sustainability. Conversely however, other research suggests that automated vehicles may encourage increased usage rates 
of vehicles, potentially worsening congestion [17]. The potential influence of automated vehicles on congestion remains a topic of contention.

Rideshare or automated vehicles may also enhance social and economic sustainability in another way. Parents may be able to undertake other tasks such as paid work without having to taxi their children. Pudāne et al. [17] used focus groups to explore individual's perceptions on how they may use automated vehicles. One factor that was highlighted by some participants was the potential for time to be saved by sending a vehicle off to undertake tasks, including transporting children. This has also been highlighted in other studies [35].

To date, no studies have explored parents' willingness to allow their unaccompanied child(ren) to use both emerging and future travel modes (e.g., rideshare vehicles and automated vehicles). The identification of key similarities and/or differences in parents willingness to allow their unaccompanied child to use these travel modes will be important for economic and social mobility, urban planning, and traffic engineering.

\section{Materials and Methods}

\subsection{Participants}

Respondents were eligible to complete an online survey if they: (a) were 18 years or older; (b) lived in Australia; (c) drove at least once per week during the period before COVID-19, and (d) lived with one or more children (aged 17 or below).

\subsection{Materials}

The online survey was completed by respondents via the Qualtrics platform (approximately $25 \mathrm{~min}$ ).

\subsubsection{Socio-Demographic Characteristics}

Respondents were asked to answer questions related to their age, gender, marital status, highest education level, household income per year (\$AUD), and state or territory of residence.

\subsubsection{Child Characteristics and Transport Patterns}

Respondents were asked questions relating to the number (and the age) of the children (aged 17 and below) living with them. Respondents with two or more children answered the remaining questions for their youngest child, including child's gender, frequency with which the child travelled in a motor vehicle (with the respondent as the driver, $1=$ Daily; $8=$ Never), the type of restraint the child used (rearward-facing child restraint, forwardfacing child restraint, booster seat, seatbelt, no restraint), the position the child was seated in the vehicle (rear seat, front passenger seat, etc.), and frequency with which the child used the restraint ( $1=$ Always; $6=$ Never). Respondents were asked whether they had previously used a rideshare vehicle with this child, and if yes, the frequency with which they used the transportation mode with this child ( $1=$ Daily; $8=$ Never).

\subsubsection{Driving and Licensing Characteristics}

Respondents were asked questions related to their annual mileage ( $\mathrm{kms})$, driving frequency ( $1=$ Daily; $5 \leq 1$ per week), crash and/or traffic infringement history in the previous two years, and the frequency of seatbelt use while travelling in a vehicle ( $1=$ Always; $6=$ Never).

\subsubsection{Driving Behaviours}

Respondents completed the Driving Behaviour Questionnaire (DBQ) [36], which contains 28-items associated with four risky driving behaviours including: (1) errors, (2) lapses, (3) violations, and (4) aggressive violations $[37,38]$. These risky driving behaviours have been associated with an increased risk of crash involvement [39]. When completing this questionnaire, respondents were asked to rate the frequency with which they had engaged 
in each driving behaviour on a six-point Likert scale $(0=$ Never; $5=$ Always $)$. Higher scores on this questionnaire are associated with higher levels of risky driving behaviours.

\subsubsection{Technology Readiness}

Respondents completed the Technology Readiness Index 2.0 (TRI 2.0) [40], which contains 16-items associated with four types of technology readiness including: (1) innovativeness, (2) optimism, (3) insecurity, and (4) discomfort. When completing this questionnaire, respondents were asked to indicate their level of agreement on a five-point Likert scale ( 1 = Strongly Disagree; $5=$ Strongly Agree). Higher scores on this questionnaire are associated with higher levels of technology adoption.

\subsubsection{Awareness of Automated Vehicles}

Respondents were asked whether they were aware of 'automated vehicles' (e.g., Yes; Not sure; No).

3.2.7. Importance of Features within Different Transportation Modes for Allowing Their Unaccompanied Child(ren) to Be Transported

Respondents completed a modified version of the Importance of Automated Vehicle Features questionnaire [11], which contains 25 vehicle features associated with four categories, including: (1) assurance (i.e., installation of a camera/microphone to see/hear the child in the vehicle), (2) safety (i.e., ability to restrain child appropriately), and (3) comfort (i.e., ability to control vehicle entertainment). When completing this questionnaire, respondents were asked to rate the importance of each feature on a four-point Likert scale $(1=$ Unnecessary to have; $2=$ Like to have; $3=$ Important to have; $4=$ Required to have). This questionnaire was completed by respondents for both rideshare vehicles and automated vehicles.

\subsubsection{Willingness to Allow Unaccompanied Child(ren) to Use Emerging and Future} Transportation Modes

Participants' willingness to allow their unaccompanied child to use emerging and future transportation modes in a (1) rideshare vehicle, and (2) an automated vehicle was rated on a four-point Likert scale ( 1 = I would never; 2 = I would be hesitant; 3 = I might; 4 = I would definitely). This technique has been used previously to explore parents' willingness to allow their child to use an automated vehicle alone $[2,8]$. These variables were the outcome measures and are described below.

\subsection{Procedure}

The Monash University Human Research Ethics Committee approved this study (MUHREC, ID 25721). Several online platforms (e.g., MUARC's Facebook and Twitter feed) were used to recruit respondents between August and November 2020. Once they had completed the survey online, respondents were directed to a link that offered them the opportunity to win one of five $\$ 100$ vouchers via a draw.

\subsection{Data Analysis}

Data were downloaded from the Qualtrics platform. Respondents were excluded if: (1) they had missing data; (2) their data were identified as an outlier (i.e., $>3$ standard deviations from the mean); and/or (3) they provided nonsensical answers to any text questions.

The outcome measures of interest were: (1) respondents' willingness to allow their child to use a rideshare vehicle alone, and (2) respondents' willingness to allow their child to use an automated vehicle alone. The majority of respondents reported that they would 'never' allow their unaccompanied child to use either a rideshare vehicle or an automated vehicle $(62.1 \%, 42.8 \%$, respectively) (see Table 1$)$. 
Table 1. Respondents' willingness to allow their unaccompanied child to use different transportation modes.

\begin{tabular}{|c|c|c|c|}
\hline & & $\begin{array}{c}\text { Rideshare } \\
\%(n)\end{array}$ & $\begin{array}{c}\text { Automated } \\
\%(n)\end{array}$ \\
\hline \multirow{4}{*}{$\begin{array}{l}\text { Willingness to allow their } \\
\text { unaccompanied child to use } \\
\text { transportation modes }\end{array}$} & I would definitely & $4.8 \%(30)$ & $8.4 \%(53)$ \\
\hline & I might & $8.9 \%(56)$ & $17.3 \%$ (109) \\
\hline & I would be hesitant & $24.2 \%(153)$ & $31.5 \%$ (199) \\
\hline & I would never & $62.1 \%(392)$ & $42.8 \%(270)$ \\
\hline
\end{tabular}

As a considerable proportion of respondents from the current sample reported that they would 'never' allow their unaccompanied child to use either of these modes, their responses were dichotomized; 'lower' willingness ('never': rideshare vehicle: $\mathrm{n}=392$, 62.1\%; automated vehicle: $\mathrm{n}=270,42.8 \%$ ) and 'higher' willingness ('definitely', 'might', 'hesitant': rideshare vehicle: $\mathrm{n}=239,37.9 \%$; automated vehicle: $\mathrm{n}=361,57.2 \%$ ).

Respondents' data were described by statistical analyses. Chi-squares analyses and Mann-Whitney U tests were conducted to explore the factors associated with parents' willingness to allow their unaccompanied child to use different transportation modes.

Confirmatory Factor Analysis (CFA) was conducted to examine the indicator loadings, and to assess internal consistency reliability (using Cronbach's alpha and composite reliability), convergent validity (using average variance extracted) and discriminant validity (using Fornell-Larcker criterion) [41,42]. Based on these analyses, measurement items with relatively low loadings (for each construct) were removed (see Tables A1-A4 in Appendix A).

To determine the factors associated with willingness to allow an unaccompanied child to use each of the transportation modes (i.e., rideshare vehicle, automated vehicle), two separate logistic regression models were conducted using the exploratory model building method outlined by Hosmer and Lemeshow [43] (i.e., there were no priori predictions regarding the direction or strength of the relationships). Univariate regression models were conducted with respondents' willingness to allow their child, unaccompanied, to use: (a) a rideshare vehicle, or (b) an automated vehicle as the dichotomous outcome variables. Predictor variables with a significance value of $p=0.25$ were included because, while they may not be predictive in the univariate model, they may influence/moderate another variable's effect. Nonsignificant variables (i.e., $p \leq 0.05$ level) were removed unless they affected the B-coefficient by more than 20 percent, and were reinserted because they were determined to be confounders [44].

All statistical analyses were conducted in IBM SPSS v.28 (IBM: Endicott, NY, USA) and SmartPLS 3 (SmartPLS GmbH: Oststeinbek, Germany).

\section{Results}

\subsection{Socio-Demographic Characteristics}

The online survey was completed by 631 respondents (see Table 2). The majority of respondents were female (63.4\%); were aged between 25 and 34 years $(32.2 \% ; \mathrm{M}=39.2$, $\mathrm{SD}=10.5$, Range $=18.0-70.0)$; were in a relationship (85.9\%); completed an undergraduate degree $(31.1 \%)$; lived in the Australian states of New South Wales or Victoria (30.6\%, $29.5 \%$, respectively), and had an annual household income of between \$AUD75,001 and \$AUD100,000 (17.7\%).

Respondents' willingness to allow their unaccompanied child to use a rideshare vehicle was significantly associated with their highest level of completed education and their annual income (Table 2). On the other hand, respondents' willingness to allow their child to use an automated vehicle unaccompanied was significantly associated with their gender, marital status, highest level of completed education, and annual income. 
Table 2. Respondents' socio-demographic characteristics and their willingness to allow their unaccompanied child to use different transportation modes.

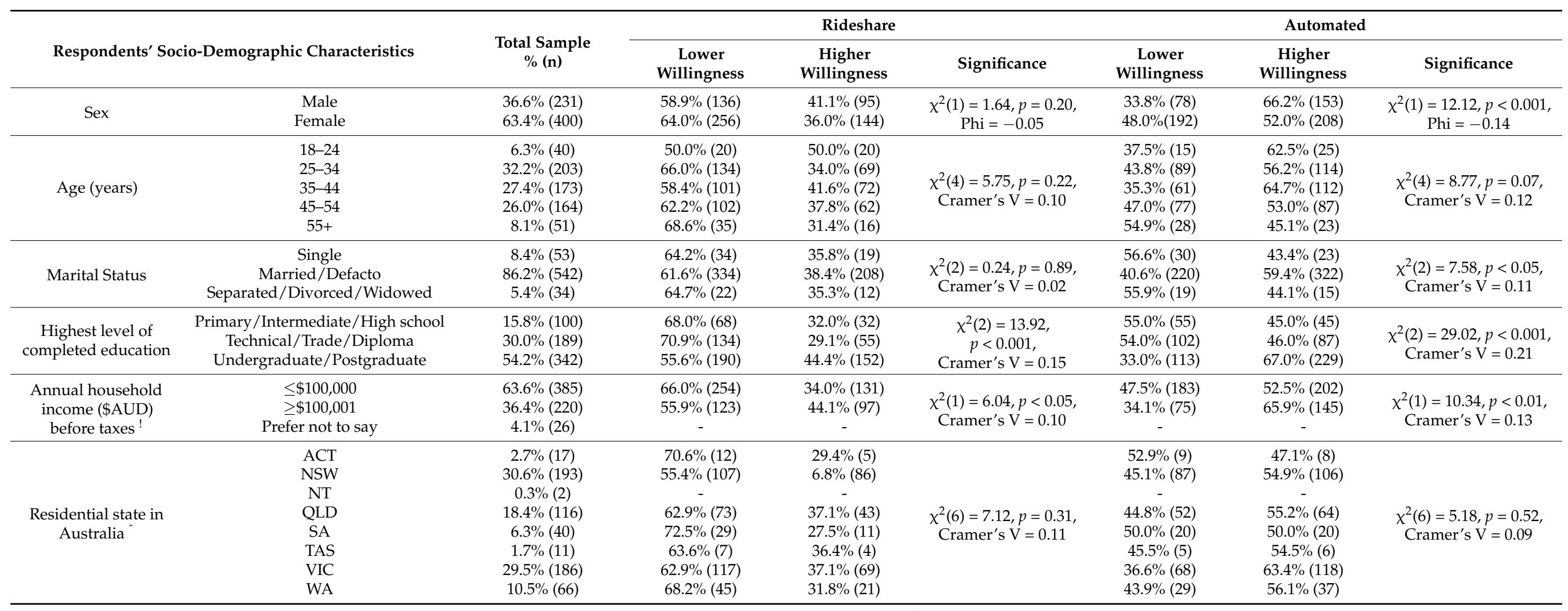

Due to small numbers, respondents from the NT were excluded from further analyses. ' Due to small numbers, respondents who reported 'Prefer not to say' were excluded from further analyses. 


\subsection{Characteristics of Respondents' Youngest Child}

The majority of respondents reported they were living with one or two children (17 years or below: 1: 46.1\%; 2: 38.8\%; 3: 13.0\%; 4: 1.6\%; 5: 0.3\%; 6: $0.2 \%$ ). As shown in Table 3 , the majority of respondents reported that their youngest child: was male $(54.2 \%)$; was aged between one and three years $(29.0 \% ; \mathrm{M}=7.2, \mathrm{SD}=5.2$, Range $=0.0-17.0)$; travelled in their vehicle, with themselves as the driver, between four and six times a week $(38.8 \%)$, was 'always' restrained in their vehicle (85.6\%); was restrained by a seatbelt $(51.1 \%)$, and was seated in the rear seat $(74.3 \%)$.

Respondents' willingness to allow their child to use a rideshare vehicle alone was significantly associated with several child-related factors. For example, respondents whose youngest child was aged 8+ years, using 'no restraint', was not 'always' restrained, and travelled in the vehicle's front seat were more willing to allow their child to use a rideshare vehicle alone. On the other hand, no child characteristics were associated with respondents' willingness to allow their child to use an automated vehicle alone.

Respondents' previous use of rideshare vehicles with their youngest child was significantly associated with their willingness to allow their unaccompanied child to use different modes. Respondents who reported that they had previously used a rideshare vehicle with their youngest child were significantly more likely to report that they would be willing to allow their child to use a rideshare vehicle or an automated vehicle alone $(55.1 \%, 64.8 \%$, respectively) compared to respondents who reported that they had not previously used a rideshare vehicle with their youngest child (rideshare: $26.1 \%, \chi^{2}(1)=54.17, p<0.001$, Phi $=0.29$; automated vehicle: $52.0 \%, \chi^{2}(1)=10.25, p<0.01$, Phi $=0.13$ ). In addition, respondents who reported that they were aware of the term 'automated vehicle' were more likely to report that they would be willing to allow their child to use an automated vehicle alone $(60.9 \%)$ compared to respondents who reported that they were not aware of the term $\left(42.4 \%, \chi^{2}(1)=13.968, p<0.001\right.$, Phi $\left.=0.15\right)$. There was no significant relationship between respondents' willingness to allow their child to use a rideshare vehicle alone and whether they were aware of the term 'automated vehicle' $\left(\chi^{2}(1)=3.703, p=0.054\right.$, Phi $\left.=0.08\right)$.

Respondents who reported that they were willing to allow their child to use a rideshare vehicle alone were also significantly more likely to report willingness to allow their child to use an automated vehicle alone $(79.1 \%)$ compared to respondents who were not willing to allow their child to use a rideshare vehicle alone $(43.9 \%), \chi^{2}(1)=75.158, p<0.001$, Phi $=0.345$.

\subsection{Driving and Licensing Characteristics}

The majority of respondents reported that they drove on a daily basis (56.3\%), 'always' wore their seatbelt $(92.6 \%)$, and had not had a crash $(90.6 \%)$ or received a driving citation in the previous two years (i.e., speeding, failing to stop) $(87.3 \%)$.

Respondents who reported that they would be willing to allow their unaccompanied child to use a rideshare vehicle reported that they had driven more kilometres over the past year, were less likely to 'always' wear they seatbelt, and were more likely to have received a driving citation in the past two years. On the other hand, respondents' willingness to allow their child to use an automated vehicle alone was significantly associated with their previous crash involvement (see Table 4). 
Table 3. Respondents' youngest child characteristics and willingness to allow their unaccompanied child to use different transportation modes.

\begin{tabular}{|c|c|c|c|c|c|c|c|c|}
\hline \multirow{2}{*}{\multicolumn{2}{|c|}{ Respondents' Youngest Child Characteristics }} & \multirow[b]{2}{*}{$\begin{array}{c}\text { Total Sample } \\
\% \text { (n) }\end{array}$} & \multicolumn{3}{|c|}{ Rideshare } & \multicolumn{3}{|c|}{ Automated } \\
\hline & & & $\begin{array}{c}\text { Lower } \\
\text { Willingness }\end{array}$ & $\begin{array}{c}\text { Higher } \\
\text { Willingness }\end{array}$ & Significance & $\begin{array}{c}\text { Lower } \\
\text { Willingness }\end{array}$ & $\begin{array}{c}\text { Higher } \\
\text { willingness }\end{array}$ & Significance \\
\hline Age group & $\begin{array}{c}<1 \text { year } \\
1-3 \text { years } \\
4-7 \text { years } \\
8-12 \text { years } \\
13-17 \text { years }\end{array}$ & $\begin{array}{c}5.2 \%(33) \\
29.0 \%(183) \\
23.0 \%(145) \\
22.5 \%(142) \\
20.3 \%(128)\end{array}$ & $\begin{array}{l}69.7 \%(23) \\
70.5 \%(129) \\
64.1 \%(93) \\
59.2 \%(84) \\
49.2 \%(63)\end{array}$ & $\begin{array}{l}30.3 \%(10) \\
29.5 \%(54) \\
35.9 \%(52) \\
40.8 \%(58) \\
50.8 \%(65)\end{array}$ & $\begin{array}{c}\chi^{2}(4)=16.09 \\
p<0.01 \\
\text { Cramer's V }=0.16\end{array}$ & $\begin{array}{l}33.3 \%(11) \\
50.3 \%(92) \\
42.8 \%(62) \\
39.4 \%(56) \\
38.3 \%(49)\end{array}$ & $\begin{array}{l}66.7 \%(22) \\
49.7 \%(91) \\
57.2 \%(83) \\
60.6 \%(86) \\
61.7 \%(79)\end{array}$ & $\begin{array}{c}\chi^{2}(4)=7.11, p=0.13 \\
\text { Cramer's V }=0.11\end{array}$ \\
\hline Sex $\#$ & $\begin{array}{l}\text { Male } \\
\text { Female } \\
\text { Other }\end{array}$ & $\begin{array}{c}54.2 \%(342) \\
45.5 \%(287) \\
0.3 \%(2)\end{array}$ & $\begin{array}{c}60.2 \%(206) \\
64.8 \%(186) \\
-\end{array}$ & $\begin{array}{c}39.8 \%(136) \\
35.2 \%(101) \\
\quad-\end{array}$ & $\begin{array}{c}\chi^{2}(1)=1.39, p=0.24 \\
\text { Phi }=-0.05\end{array}$ & $\begin{array}{c}39.5 \%(135) \\
46.7 \%(134) \\
-\end{array}$ & $\begin{array}{c}60.5 \%(207) \\
53.3 \%(153) \\
\quad-\end{array}$ & $\begin{array}{c}\chi^{2}(1)=3.32, p=0.07 \\
\text { Phi }=-0.07\end{array}$ \\
\hline $\begin{array}{l}\text { Frequency of vehicle } \\
\text { travel }\end{array}$ & $\begin{array}{c}\text { Daily } \\
4-6 \text { times per week } \\
2-3 \text { times per week } \\
\leq 1 \text { time per week }\end{array}$ & $\begin{array}{c}29.3 \%(185) \\
38.8 \%(245) \\
22.3 \%(141) \\
9.5 \%(60)\end{array}$ & $\begin{array}{l}60.5 \%(112) \\
62.4 \%(153) \\
62.4 \%(88) \\
65.0 \%(39) \\
\end{array}$ & $\begin{array}{l}39.5 \%(73) \\
37.6 \%(92) \\
37.6 \%(53) \\
35.0 \%(21)\end{array}$ & $\begin{array}{c}\chi^{2}(3)=0.42, p=0.94 \\
\text { Cramer's V }=0.03\end{array}$ & $\begin{array}{c}42.7 \%(79) \\
44.9 \%(110) \\
40.4 \%(57) \\
40.0 \%(24) \\
\end{array}$ & $\begin{array}{c}57.3 \%(106) \\
55.1 \%(135) \\
59.6 \%(84) \\
60.0 \%(36)\end{array}$ & $\begin{array}{c}\chi^{2}(3)=0.96, p=0.81 \\
\text { Cramer's V }=0.04\end{array}$ \\
\hline Type of restraint & $\begin{array}{c}\text { Rearward-facing CRS } \\
\text { Forward-facing CRS } \\
\text { Booster seat } \\
\text { Seatbelt } \\
\text { No restraint }\end{array}$ & $\begin{array}{c}11.3 \%(71) \\
22.3 \%(141) \\
21.7 \%(137) \\
41.8 \%(264) \\
2.9 \%(18)\end{array}$ & $\begin{array}{c}73.2 \%(52) \\
71.6 \%(101) \\
66.4 \%(91) \\
54.2 \%(143) \\
27.8 \%(5)\end{array}$ & $\begin{array}{c}26.8 \%(19) \\
28.4 \%(40) \\
33.6 \%(46) \\
45.8 \%(121) \\
72.2 \%(13)\end{array}$ & $\begin{array}{c}\chi^{2}(4)=26.35 \\
p<0.001 \\
\text { Cramer's V }=0.20\end{array}$ & $\begin{array}{c}43.7 \%(31) \\
49.6 \%(70) \\
41.6 \%(57) \\
40.2 \%(106) \\
33.3 \%(6)\end{array}$ & $\begin{array}{c}56.3 \%(40) \\
50.4 \%(71) \\
58.4 \%(80) \\
59.8 \%(158) \\
66.7 \%(12)\end{array}$ & $\begin{array}{c}\chi^{2}(4)=4.22, p=0.34 \\
\text { Cramer's V }=0.08\end{array}$ \\
\hline $\begin{array}{l}\text { Vehicle seating } \\
\text { position * }\end{array}$ & $\begin{array}{c}\text { Front passenger seat } \\
\text { Rear seat (back seat of passenger } \\
\text { vehicle, 2nd or 3rd row of minivan) } \\
\text { Someone's lap }\end{array}$ & $\begin{array}{c}25.0 \%(158) \\
74.3 \%(469) \\
0.6 \%(4)\end{array}$ & $\begin{array}{c}45.6 \%(72) \\
68.0 \%(319) \\
-\end{array}$ & $\begin{array}{c}54.4 \%(86) \\
32.0 \%(150) \\
-\end{array}$ & $\begin{array}{c}\chi^{2}(1)=25.37 \\
p<0.001 \\
\text { Phi }=-0.20\end{array}$ & $\begin{array}{c}36.7 \%(58) \\
44.6 \%(209) \\
-\end{array}$ & $\begin{array}{l}63.3 \%(100) \\
55.4 \%(260) \\
-\end{array}$ & $\begin{array}{c}\chi^{2}(1)=2.98, p=0.08 \\
\text { Phi }=-0.07\end{array}$ \\
\hline
\end{tabular}

\# Due to small numbers for 'Other', the analyses only included 'Males' and 'Females'. * Due to small numbers for 'Someone's lap', the analyses only included 'Front passenger seat' and ‘Rear seat'. 
Table 4. Respondents' driving characteristics and their willingness to allow their unaccompanied child to use different transportation modes.

\begin{tabular}{|c|c|c|c|c|c|c|c|c|}
\hline \multirow{2}{*}{\multicolumn{2}{|c|}{ Respondents' Driving Characteristics }} & \multirow[b]{2}{*}{$\begin{array}{l}\text { Total Sample } \\
\quad \%(n)\end{array}$} & \multicolumn{3}{|c|}{ Rideshare } & \multicolumn{3}{|c|}{ Automated } \\
\hline & & & $\begin{array}{c}\text { Lower } \\
\text { Willingness }\end{array}$ & $\begin{array}{c}\text { Higher } \\
\text { Willingness }\end{array}$ & Significance & $\begin{array}{c}\text { Lower } \\
\text { Willingness }\end{array}$ & $\begin{array}{c}\text { Higher } \\
\text { Willingness }\end{array}$ & Significance \\
\hline \multirow{4}{*}{ Driving frequency } & Daily & $56.3 \%(355)$ & $57.7 \%(226)$ & $54.0 \%(129)$ & \multirow{4}{*}{$\begin{array}{c}\chi^{2}(3)=2.15, p=0.54 \\
\text { Cramer's V = 0.06 }\end{array}$} & $43.1 \%(153)$ & $56.9 \%(202)$ & \multirow{4}{*}{$\begin{array}{c}\chi^{2}(3)=1.44, p=0.70 \\
\text { Cramer's V }=0.05\end{array}$} \\
\hline & 4-6 times per week & $31.5 \%$ (199) & $29.6 \%(116)$ & $34.7 \%(83)$ & & $40.2 \%(80)$ & $59.8 \%(119)$ & \\
\hline & 2-3 times per week & $9.5 \%(60)$ & $9.7 \%(38)$ & $9.2 \%(22)$ & & $48.3 \%(29)$ & $51.7 \%(31)$ & \\
\hline & $\leq 1$ time per week & $2.7 \%(17)$ & $3.1 \%(12)$ & $2.1 \%(5)$ & & $47.1 \%(8)$ & $52.9 \%(9)$ & \\
\hline \multirow{3}{*}{$\begin{array}{l}\text { Estimated annual mileage } \\
\qquad(\mathrm{kms})\end{array}$} & $\leq 5000 \mathrm{~km}$ & $20.3 \%(128)$ & $23.0 \%(90)$ & $15.9 \%(38)$ & \multirow{3}{*}{$\begin{array}{c}\chi^{2}(2)=11.87 \\
p<0.01, \text { Cramer's } \\
\text { V }=0.14\end{array}$} & $44.5 \%(57)$ & $55.5 \%(71)$ & \multirow{3}{*}{$\begin{array}{c}\chi^{2}(2)=2.62, p=0.27 \\
\text { Cramer's V }=0.06\end{array}$} \\
\hline & $5001-15,000 \mathrm{~km}$ & $46.6 \%(294)$ & $48.7 \%(191)$ & $43.1 \%(103)$ & & $45.2 \%(133)$ & $54.8 \%(161)$ & \\
\hline & $\geq 15,001 \mathrm{~km}$ & $33.1 \%(209)$ & $28.3 \%(111)$ & $41.0 \%(98)$ & & $38.3 \%(80)$ & $61.7 \%(129)$ & \\
\hline \multirow[b]{2}{*}{ Frequency of seatbelt use } & Always & $92.6 \%(584)$ & $95.2 \%(373)$ & $88.3 \%(211)$ & \multirow{2}{*}{$\begin{array}{c}\chi^{2}(1)=10.16 \\
p<0.01, \text { Phi }=0.13\end{array}$} & $43.2 \%(252)$ & $56.8 \%(332)$ & \multirow{2}{*}{$\begin{array}{c}\chi^{2}(1)=0.42, p=0.52, \\
\text { Phi }=0.03\end{array}$} \\
\hline & $\begin{array}{l}\text { Almost always/Usually/ } \\
\text { Sometimes/Almost never/Never }\end{array}$ & $7.4 \%(47)$ & $4.8 \%(19)$ & $11.7 \%(28)$ & & $38.3 \%(18)$ & $61.7 \%(29)$ & \\
\hline \multirow{2}{*}{$\begin{array}{l}\text { Had a crash while driving in } \\
\text { the past two years? }\end{array}$} & No & $90.6 \%(572)$ & $7.9 \%(31)$ & $11.7 \%(28)$ & \multirow{2}{*}{$\begin{array}{c}\chi^{2}(1)=2.54, p=0.11 \\
\text { Phi }=-0.06\end{array}$} & $44.2 \%(253)$ & $55.8 \%(319)$ & \multirow{2}{*}{$\begin{array}{c}\chi^{2}(1)=5.19, p<0.05 \\
P h i=-0.09\end{array}$} \\
\hline & Yes & $9.4 \%(59)$ & $92.1 \%(361)$ & $88.3 \%(211)$ & & $28.8 \%(17)$ & $71.2 \%(42)$ & \\
\hline \multirow{2}{*}{$\begin{array}{l}\text { Had an at-fault crash while } \\
\text { driving in the past two years? }\end{array}$} & No & $95.1 \%(600)$ & $3.8 \%(15)$ & $6.7 \%(16)$ & \multirow{2}{*}{$\begin{array}{c}\chi^{2}(1)=2.61, p=0.11 \\
\text { Phi }=-0.06\end{array}$} & $43.7 \%(262)$ & $56.3 \%(338)$ & \multirow{2}{*}{$\begin{array}{c}\chi^{2}(1)=3.84, p=0.05 \\
\text { Phi }=-0.08\end{array}$} \\
\hline & Yes & $4.9 \%(31)$ & $96.2 \%$ (377) & $93.3 \%(223)$ & & $25.8 \%(8)$ & $74.2 \%(23)$ & \\
\hline \multirow{2}{*}{$\begin{array}{l}\text { Received a driving citation in } \\
\text { the past two years }\end{array}$} & No & $87.3 \%$ (551) & $90.6 \%$ (355) & $82.0 \%(196)$ & \multirow{2}{*}{$\begin{array}{c}\chi^{2}(1)=9.81, p<0.01 \\
\text { Phi }=0.13\end{array}$} & $43.4 \%$ (239) & $56.6 \%(312)$ & \multirow{2}{*}{$\begin{array}{c}\chi^{2}(1)=0.61, p=0.44 \\
\text { Phi }=0.03\end{array}$} \\
\hline & Yes & $12.7 \%(80)$ & $9.4 \%(37)$ & $18.0 \%(43)$ & & $38.8 \%(31)$ & $61.3 \%(4) 9$ & \\
\hline
\end{tabular}




\subsection{Driving Behaviours}

Respondents' risky driving behaviours were significantly associated with their willingness to allow their unaccompanied child to use different transportation modes (see Table 5). Respondents reporting greater levels of willingness to allow their child to use a rideshare vehicle unaccompanied also reported higher levels of risky driving behaviours, including errors, lapses, violations, and aggressive violations. Similarly, respondents' willingness to allow their child to use an automated vehicle alone was associated with higher levels of errors, violations and aggressive violations, but not lapses.

Table 5. Respondents' self-reported risky driving behaviours and their willingness to allow their unaccompanied child to use different transportation modes.

\begin{tabular}{|c|c|c|c|c|c|c|c|c|c|}
\hline \multirow[b]{2}{*}{$\begin{array}{l}\text { Respondents' } \\
\text { Responses }\end{array}$} & \multirow[b]{2}{*}{$\begin{array}{c}\text { Median } \\
\text { (IQ1, IQ3) }\end{array}$} & \multirow[b]{2}{*}{ Range } & \multirow[b]{2}{*}{$\begin{array}{c}\text { Cronbach's } \\
\alpha\end{array}$} & \multicolumn{3}{|c|}{ Rideshare } & \multicolumn{3}{|c|}{ Automated } \\
\hline & & & & $\begin{array}{c}\text { Lower } \\
\text { Willingness } \\
\text { Median } \\
\text { (IQ1, IQ3) }\end{array}$ & $\begin{array}{c}\text { Higher } \\
\text { Willingness } \\
\text { Median } \\
\text { (IQ1, IQ3) }\end{array}$ & Significance & $\begin{array}{c}\text { Lower } \\
\text { Willingness } \\
\text { Median } \\
\text { (IQ1, IQ3) }\end{array}$ & $\begin{array}{c}\text { Higher } \\
\text { Willingness } \\
\text { Median } \\
\text { (IQ1, IQ3) }\end{array}$ & Significance \\
\hline $\begin{array}{c}\text { DBQ Errors: } \\
\text { Average }(\mathrm{n}=4)\end{array}$ & $\begin{array}{c}0.00 \\
(0.00,0.50)\end{array}$ & $0.00-5.00$ & 0.940 & $\begin{array}{c}0.00 \\
(0.00,0.50)\end{array}$ & $\begin{array}{c}0.25 \\
(0.00,1.00)\end{array}$ & $\begin{array}{c}\mathrm{U}=36,743.00 \\
\mathrm{Z}=-4.94 \\
p<0.001\end{array}$ & $\begin{array}{c}0.00 \\
(0.00,0.31)\end{array}$ & $\begin{array}{c}0.25 \\
(0.00,0.75)\end{array}$ & $\begin{array}{c}\mathrm{U}=43,214.50, \\
\mathrm{Z}=-2.65, \\
p<0.01\end{array}$ \\
\hline $\begin{array}{c}\text { DBQ Lapses: } \\
\text { Average }(\mathrm{n}=3)\end{array}$ & $\begin{array}{c}0.67 \\
(0.00,1.00)\end{array}$ & $0.00-5.00$ & 0.827 & $\begin{array}{c}0.67 \\
(0.00,1.00)\end{array}$ & $\begin{array}{c}1.00 \\
(0.33,1.33)\end{array}$ & $\begin{array}{c}\mathrm{U}=37,480.00 \\
\mathrm{Z}=-4.30 \\
p<0.001\end{array}$ & $\begin{array}{c}0.67 \\
(0.00,1.00)\end{array}$ & $\begin{array}{c}0.67 \\
(0.00,1.33)\end{array}$ & $\begin{array}{c}\mathrm{U}=45,000.00, \\
\mathrm{Z}=-1.68, \\
p=0.09\end{array}$ \\
\hline $\begin{array}{l}\text { DBQ Aggressive } \\
\text { violations: Average } \\
(\mathrm{n}=2)\end{array}$ & $\begin{array}{c}0.00 \\
(0.00,1.00)\end{array}$ & $0.00-5.00$ & 0.803 & $\begin{array}{c}0.00 \\
(0.00,0.50)\end{array}$ & $\begin{array}{c}0.50 \\
(0.00,1.00)\end{array}$ & $\begin{array}{c}\mathrm{U}=35,363.50 \\
\mathrm{Z}=-5.59 \\
p<0.001\end{array}$ & $\begin{array}{c}0.00 \\
(0.00,0.50)\end{array}$ & $\begin{array}{c}0.50 \\
(0.00,1.00)\end{array}$ & $\begin{array}{c}\mathrm{U}=43,255.50, \\
\mathrm{Z}=-2.49, \\
p<0.05\end{array}$ \\
\hline $\begin{array}{l}\text { DBQ Violations: } \\
\text { Average }(\mathrm{n}=4)\end{array}$ & $\begin{array}{c}0.25 \\
(0.00,1.00)\end{array}$ & $0.00-5.00$ & 0.917 & $\begin{array}{c}0.25 \\
(0.00,0.75)\end{array}$ & $\begin{array}{c}0.50 \\
(0.25,1.25)\end{array}$ & $\begin{array}{c}\mathrm{U}=34,047.00 \\
\mathrm{Z}=-5.93 \\
p<0.001\end{array}$ & $\begin{array}{c}0.25 \\
(0.00,0.75)\end{array}$ & $\begin{array}{c}0.50 \\
(0.00,1.00)\end{array}$ & $\begin{array}{c}\mathrm{U}=43,169.00, \\
\mathrm{Z}=-2.66 \\
p<0.01\end{array}$ \\
\hline
\end{tabular}

\subsection{Technology Readiness}

Respondents' technology readiness or adoption was significantly associated with their willingness to allow their child to use different transportation modes unaccompanied (see Table 6). Respondents who reported a willingness to allow their child to use a rideshare vehicle or an automated vehicle alone were also more likely to consider technology to be innovative and to view it optimistically.

Table 6. Respondents' self-reported technology readiness and their willingness to allow their unaccompanied child to use different transportation modes.

\begin{tabular}{|c|c|c|c|c|c|c|c|c|c|}
\hline \multirow[b]{2}{*}{$\begin{array}{l}\text { Respondents' } \\
\text { Responses }\end{array}$} & \multirow[b]{2}{*}{$\begin{array}{c}\text { Median } \\
\text { (IQ1, IQ3) }\end{array}$} & \multirow[b]{2}{*}{ Range } & \multirow[b]{2}{*}{$\begin{array}{c}\text { Cronbach's } \\
\alpha\end{array}$} & \multicolumn{3}{|c|}{ Rideshare } & \multicolumn{3}{|c|}{ Automated } \\
\hline & & & & $\begin{array}{c}\text { Lower } \\
\text { Willingness } \\
\text { Median } \\
\text { (IQ1, IQ3) }\end{array}$ & $\begin{array}{c}\text { Higher } \\
\text { Willingness } \\
\text { Median } \\
\text { (IQ1, IQ3) }\end{array}$ & Significance & $\begin{array}{c}\text { Lower } \\
\text { Willingness } \\
\text { Median } \\
\text { (IQ1, IQ3) }\end{array}$ & $\begin{array}{c}\text { Higher } \\
\text { Willingness } \\
\text { Median } \\
\text { (IQ1, IQ3) }\end{array}$ & Significance \\
\hline $\begin{array}{l}\text { TRI Optimism } \\
\qquad(\mathrm{n}=4)\end{array}$ & $\begin{array}{c}16.00 \\
(14.00,18.00)\end{array}$ & $4.00-20.00$ & 0.89 & $\begin{array}{c}16.00 \\
(14.00,17.00)\end{array}$ & $\begin{array}{c}16.00 \\
(14.00,18.00)\end{array}$ & $\begin{array}{c}\mathrm{U}=42,202.00 \\
\mathrm{Z}=-2.11 \\
p<0.05\end{array}$ & $\begin{array}{c}16.00 \\
(12.00,17.00)\end{array}$ & $\begin{array}{c}16.00 \\
(14.00,18.00)\end{array}$ & $\begin{array}{c}\mathrm{U}=38,850.50 \\
\mathrm{Z}=-4.403 \\
p<0.001\end{array}$ \\
\hline $\begin{array}{c}\text { TRI } \\
\text { Innovativeness } \\
(\mathrm{n}=4)\end{array}$ & $\begin{array}{c}13.00 \\
(11.00,16.00)\end{array}$ & $4.00-20.00$ & 0.88 & $\begin{array}{c}13.00 \\
(10.00,16.00)\end{array}$ & $\begin{array}{c}14.00 \\
(12.00,16.00)\end{array}$ & $\begin{array}{c}\mathrm{U}=38,699.50 \\
\mathrm{Z}=-3.68 \\
p<0.001\end{array}$ & $\begin{array}{c}12.00 \\
(9.00,15.00)\end{array}$ & $\begin{array}{c}14.00 \\
(12.00,16.00)\end{array}$ & $\begin{array}{c}\mathrm{U}=33,198.00 \\
\mathrm{Z}=-6.88 \\
p<0.001\end{array}$ \\
\hline $\begin{array}{l}\text { TRI Comfort } \\
\quad(\mathrm{n}=2)\end{array}$ & $\begin{array}{c}6.00 \\
(4.00,7.00)\end{array}$ & $2.00-10.00$ & 0.82 & $\begin{array}{c}6.00 \\
(5.00,7.00)\end{array}$ & $\begin{array}{c}6.00 \\
(4.00,7.00)\end{array}$ & $\begin{array}{c}\mathrm{U}=44,258.50 \\
\mathrm{Z}=-1.18 \\
p=0.24\end{array}$ & $\begin{array}{c}4.00 \\
(3.00,6.00)\end{array}$ & $\begin{array}{c}4.00 \\
(4.00,6.00)\end{array}$ & $\begin{array}{c}\mathrm{U}=43,386.00 \\
\mathrm{Z}=-2.40 \\
p<0.05\end{array}$ \\
\hline $\begin{array}{l}\text { TRI Security } \\
\qquad(\mathrm{n}=2)\end{array}$ & $\begin{array}{c}4.00 \\
(3.00,6.00)\end{array}$ & $2.00-10.00$ & 0.78 & $\begin{array}{c}4.00 \\
(3.00,6.00)\end{array}$ & $\begin{array}{c}4.00 \\
(4.00,6.00)\end{array}$ & $\begin{array}{c}\mathrm{U}=41,826.00 \\
\mathrm{Z}=-2.30 \\
p<0.05\end{array}$ & $\begin{array}{c}6.00 \\
(4.75,7.00)\end{array}$ & $\begin{array}{c}6.00 \\
(4.00,7.00)\end{array}$ & $\begin{array}{c}\mathrm{U}=47,561.00 \\
\mathrm{Z}=-0.53 \\
p=0.60\end{array}$ \\
\hline
\end{tabular}




\subsection{Respondents' Ratings of the Importance of Vehicle Features for Transporting Their Unaccompanied Children}

Respondents rated the importance of features within the two transportation modes for allowing their child to travel alone (i.e., GPS to track the vehicle's location, ability to see and hear the child, etc.) (see Table 7). Respondents who were willing to allow their child to use a rideshare vehicle or automated vehicle alone were significantly less likely to require vehicle features related to child safety, assurance, route control, and comfort.

Table 7. Respondents' ratings of the importance of features and their willingness to allow their unaccompanied child to use different transportation modes.

\begin{tabular}{|c|c|c|c|c|c|c|c|c|c|}
\hline \multirow[b]{2}{*}{$\begin{array}{l}\text { Respondents' } \\
\text { Ratings of the } \\
\text { Importance of } \\
\text { Features }\end{array}$} & \multirow[b]{2}{*}{$\begin{array}{l}\text { Median } \\
\text { (IQ1, IQ3) }\end{array}$} & \multirow[b]{2}{*}{ Range } & \multirow[b]{2}{*}{$\begin{array}{c}\text { Cronbach's } \\
\alpha\end{array}$} & \multicolumn{3}{|c|}{ Rideshare Vehicle } & \multicolumn{3}{|c|}{ Automated Vehicle } \\
\hline & & & & $\begin{array}{c}\text { Lower } \\
\text { Willingness } \\
\text { Median } \\
\text { (IQ1, IQ3) }\end{array}$ & $\begin{array}{c}\text { Higher } \\
\text { Willingness } \\
\text { Median } \\
\text { (IQ1, IQ3) }\end{array}$ & Significance & $\begin{array}{c}\text { Lower } \\
\text { Willingness } \\
\text { Median } \\
\text { (IQ1, IQ3) }\end{array}$ & $\begin{array}{c}\text { Higher } \\
\text { Willingness } \\
\text { Median } \\
\text { (IQ1, IQ3) }\end{array}$ & Significance \\
\hline $\begin{array}{c}\text { Route } \\
\text { control-Average } \\
(\mathrm{n}=4)\end{array}$ & $\begin{array}{c}3.50 \\
(2.75,4.00)\end{array}$ & $1.00-4.00$ & 0.88 & $\begin{array}{c}3.75 \\
(3.25,4.00)\end{array}$ & $\begin{array}{c}3.00 \\
(2.50,3.50)\end{array}$ & $\begin{array}{c}\mathrm{U}=26,638.50 \\
\mathrm{Z}=-9.32 \\
p<0.001\end{array}$ & $\begin{array}{c}3.75 \\
(3.00,4.00)\end{array}$ & $\begin{array}{c}3.25 \\
(2.75,3.75)\end{array}$ & $\begin{array}{c}\mathrm{U}=35,129.50, \\
\mathrm{Z}=-6.15, \\
p<0.001\end{array}$ \\
\hline $\begin{array}{c}\text { Assurance- } \\
\text { Average } \\
(\mathrm{n}=8)\end{array}$ & $\begin{array}{c}3.25 \\
(2.63,3.88)\end{array}$ & $1.00-4.00$ & 0.92 & $\begin{array}{c}3.50 \\
(3.00,4.00)\end{array}$ & $\begin{array}{c}2.75 \\
(2.38,3.38)\end{array}$ & $\begin{array}{c}\mathrm{U}=25,713.50 \\
\mathrm{Z}=-9.58 \\
p<0.001\end{array}$ & $\begin{array}{c}3.50 \\
(2.88,4.00)\end{array}$ & $\begin{array}{c}3.00 \\
(2.50,3.63)\end{array}$ & $\begin{array}{c}\mathrm{U}=35,408.00, \\
\mathrm{Z}=-5.92, \\
p<0.001\end{array}$ \\
\hline $\begin{array}{c}\text { Child } \\
\text { safety-Average } \\
(\mathrm{n}=7)\end{array}$ & $\begin{array}{c}3.86 \\
(3.14,4.00)\end{array}$ & $1.00-4.00$ & 0.92 & $\begin{array}{c}4.00 \\
(3.57,4.00)\end{array}$ & $\begin{array}{c}3.43 \\
(2.71,3.86)\end{array}$ & $\begin{array}{c}\mathrm{U}=26,132.00 \\
\mathrm{Z}=-9.69 \\
p<0.001\end{array}$ & $\begin{array}{c}3.00 \\
(2.00,3.75)\end{array}$ & $\begin{array}{c}2.50 \\
(1.75,3.25)\end{array}$ & $\begin{array}{c}\mathrm{U}=40,601.00, \\
\mathrm{Z}=-3.61 \\
p<0.001\end{array}$ \\
\hline $\begin{array}{l}\text { Comfort-Average } \\
\qquad(\mathrm{n}=4)\end{array}$ & $\begin{array}{c}2.75 \\
(1.75,3.50)\end{array}$ & $1.00-4.00$ & 0.91 & $\begin{array}{c}2.75 \\
(2.00,3.75)\end{array}$ & $\begin{array}{c}2.50 \\
(1.50,3.00)\end{array}$ & $\begin{array}{c}\mathrm{U}=36,405.50 \\
\mathrm{Z}=-4.72 \\
p<0.001\end{array}$ & $\begin{array}{c}4.00 \\
(3.43,4.00)\end{array}$ & $\begin{array}{c}3.57 \\
(3.00,4.00)\end{array}$ & $\begin{array}{c}\mathrm{U}=37,234.50, \\
\mathrm{Z}=-5.27, \\
p<0.001\end{array}$ \\
\hline
\end{tabular}

4.7. Factors Associated with Respondents' Willingness to Allow Their Child to Use Different Transportation Modes Alone

Two logistic regression models were conducted to explore the factors associated with respondents' willingness to allow their child to use different transportation modes alone.

\subsubsection{Respondents' Willingness to Allow Their Child to Use a Rideshare Vehicle Alone}

The model identified several factors associated with respondents' willingness to allow their child to use a rideshare vehicle alone, $\chi^{2}(7)=159.59, p<0.001$, with the HosmerLemeshow Goodness-of-fit suggesting good model fit, $p>0.05$. The model explained 30.4\% (Nagelkerke R squared) of the variance in respondents' willingness to allow their child to use a rideshare vehicle alone. The model correctly classified $79.0 \%$ of respondents, and the ROC curve indicated an 'acceptable' level of discrimination [43].

As shown in Table 8, the factors associated with respondents' willingness to allow their child to use a rideshare vehicle alone included:

- Previously used a rideshare vehicle with their youngest child: relative to respondents who reported that they had not previously used a rideshare vehicle with their youngest child, respondents who reported that they had used a rideshare vehicle with their youngest child had 2.5 times higher odds of being willing to allow their child to use a rideshare vehicle alone.

- Annual mileage ( $\mathrm{kms})$ : relative to respondents who estimated that they had driven $<5000 \mathrm{~km}$ in the previous year, respondents estimating that they had driven $>15,001 \mathrm{~km}$ had 1.9 times higher odds of being willing to allow their unaccompanied child to use a rideshare vehicle.

- DBQ violations: for every one score increase in their violations, respondents' willingness to allow their child to use a rideshare vehicle alone significantly increased by $33 \%$.

- TRI optimism: for every one score increase in their optimism regarding technology, respondents' willingness to allow their child to use a rideshare vehicle alone significantly increased by $9 \%$. 
- Importance of route control related vehicle features: for every one score increase in the importance of the rideshare vehicle having route control features, respondents had $41 \%$ lower odds of being willing to allow their child to use a rideshare vehicle alone.

- Importance of assurance vehicle features: for every one score increase in the importance of the rideshare vehicles having assurance-related features, respondents had $52 \%$ lower odds of being willing to allow their child to use a rideshare vehicle alone.

Table 8. Odds ratios ( $95 \% \mathrm{CI}$ ) of the key variables associated with respondents' willingness to allow their child to use a rideshare vehicle alone.

\begin{tabular}{ccccccc}
\hline & & B & S.E. & Exp(B) & Sig. & 95\% C.I. \\
\hline Used rideshare vehicle with & No & - & - & - & - & - \\
youngest child previously & Yes & 0.923 & 0.197 & 2.518 & $<0.001$ & $1.711,3.705$ \\
\hline \multirow{2}{*}{ Annual mileage $(\mathrm{kms})$} & $<5000 \mathrm{~km}$ & - & - & - & - & - \\
\cline { 2 - 7 } & $5001-15,000 \mathrm{~km}$ & 0.506 & 0.262 & 1.658 & 0.053 & $0.992,2.770$ \\
\hline & $>15,001 \mathrm{~km}$ & 0.628 & 0.275 & 1.874 & $<0.05$ & $1.093,3.212$ \\
\hline DBQ_VIOLATIONS & & 0.284 & 0.102 & 1.328 & $<0.01$ & $1.088,1.622$ \\
\hline TRI-OPTIMISM & & 0.089 & 0.032 & 1.093 & $<0.01$ & $1.027,1.163$ \\
\hline ROUTE CONTROL FEATURES & & -0.523 & 0.184 & 0.593 & $<0.01$ & $0.413,0.851$ \\
\hline ASSURANCE FEATURES & & -0.737 & 0.183 & 0.478 & $<0.001$ & $0.335,0.684$ \\
\hline
\end{tabular}

4.7.2. Respondents' Willingness to Allow Their Child to Use an Automated Vehicle Alone

The model identified several factors associated with respondents' willingness to allow their child to use an automated vehicle alone, $\chi^{2}(6)=113.325, p<0.001$, with the HosmerLemeshow Goodness-of-fit suggesting good model fit, $p>0.05$. The model explained $22.1 \%$ (Nagelkerke R squared) of the variance in respondents' willingness to use an automated vehicle to transport their child alone. The model correctly classified $73.1 \%$ of respondents, and the ROC curve indicated an 'acceptable' level of discrimination [43].

As shown in Table 9, the factors associated with respondents' willingness to allow their child to use an automated vehicle alone included:

- Awareness of automated vehicles: compared to respondents who reported that they had not heard of automated vehicles, respondents who reported that they had heard of automated vehicles had 1.809 higher odds of being willing to allow their child to use an automated vehicle alone.

- Education: compared to respondents who had completed education to a primary or secondary level, respondents who had completed an undergraduate or postgraduate degree had 1.840 higher odds of being willing to allow their child to use an automated vehicle alone.

- TRI innovation: for every one score increase in rating technology as innovative, respondents' willingness to allow their child to use an automated vehicle alone significantly increased by $11 \%$.

- TRI optimism: for every one score increase in their optimism regarding technology, respondents' willingness to allow their child to use an automated vehicle alone significantly increased by 10 percent.

- Importance of route control vehicle features: for every one score increase in the importance of requiring the automated vehicle to have route control related features, respondents had $53 \%$ lower odds of being willing to allow their child to use an automated vehicle alone. 
Table 9. Odds ratios ( $95 \% \mathrm{CI}$ ) of the key variables associated with respondents' willingness to allow their child to use an automated vehicle alone.

\begin{tabular}{ccccccc}
\hline & & B & S.E. & Exp(B) & Sig. & 95\% C.I. \\
\hline \multirow{2}{*}{ Awareness of automated vehicles } & No & - & - & - & - & - \\
& Yes & 0.593 & 0.219 & 1.809 & $<0.05$ & $1.178,2.777$ \\
\hline \multirow{2}{*}{ Education level completed } & Primary/High school & - & - & - & - & - \\
\cline { 2 - 7 } & Technical/Trade/Diploma & -0.011 & 0.268 & 0.989 & 0.967 & $0.585,1.673$ \\
\cline { 2 - 7 } & Undergraduate/Postgraduate & 0.610 & 0.253 & 1.840 & $<0.05$ & $1.122,3.019$ \\
\hline TRI-INNOVATIVENESS & & 0.107 & 0.025 & 1.113 & $<0.001$ & $1.059,1.170$ \\
\hline TRI-OPTIMISM & & 0.092 & 0.032 & 1.096 & $<0.01$ & $1.029,1.168$ \\
\hline ROUTE CONTROL FEATURES & & -0.749 & 0.136 & 0.473 & $<0.001$ & $0.363,0.617$ \\
\hline
\end{tabular}

\section{Discussion}

This study examined the factors associated with parents' willingness to allow their child(ren) to use emerging and future travel modes alone, namely rideshare vehicles and automated vehicles. To the best of the authors' knowledge, this is the first study to explore parents' willingness to use these two transportation modes within the same sample of respondents. Notwithstanding that these two transportation modes are not equally accessible at present and have different operational mechanisms, they are both relatively futuristic, but potentially equally likely to be alternative sources of transportation for parents. This is, therefore, an important research topic because there is an increasing emphasis om using travel modes that are safe, affordable, accessible, and sustainable [1].

The majority of respondents in this study expressed that they would 'never' allow their unaccompanied child to use different transportation modes (i.e., either a rideshare vehicle or an automated vehicle) $(62.1 \%$ and $42.8 \%$, respectively). The proportion of respondents who reported they would 'never' allow their child to use an automated vehicle alone is consistent with that reported by Koppel et al. [14] within an independent Australian sample (43.5\%). The higher proportion of respondents who reported that they would 'never' allow their child to use a rideshare vehicle alone, compared to an automated vehicle unaccompanied, is an interesting finding. The two transportation modes, though similar in some ways, have different modus operandi which may explain the finding that individuals have lower levels of trust in rideshare companies, or alternatively, of drivers who operate rideshare vehicles. Previously, concerns about personal safety and security in relation to rideshare drivers has been recognised as a factor that can influence willingness to use rideshare vehicles $[9,10]$. Alternatively, parents may feel more confident knowing that, when travelling in an automated vehicle, a child is not in the care of an unknown person. In addition to the issues of safety explored above, affordability of child-friendly transportation modes has also been shown to be an important factor [20]. While the current study did not specifically explore whether the affordability of these modes influenced respondents' willingness to use them, there were significant relationships between respondents' annual household income and their willingness to use both modes. Future research should explicitly explore the relationship between affordability and intentions to use emerging and future transport modes.

When drawing comparisons between the key factors that predicted parents' willingness to allow their child to use rideshare vehicles and/or automated vehicles alone, both similarities and differences emerged. The first similarity identified was that previous experience (of rideshare) or awareness (of automated vehicles) was associated with a greater level of willingness to allow their unaccompanied child to use the transportation mode. Second, higher levels of technology-related 'optimism' were associated with a higher level of willingness to allow their unaccompanied child to use a rideshare vehicle or an automated vehicle. Third, respondents who expressed higher levels of the importance 
of vehicle features (i.e., ability to see and hear their child in the vehicle, GPS to track the location of the vehicle, etc.) had lower levels of willingness to allow their child to use either a rideshare vehicle or an automated vehicle alone.

Considering unique patterns that predict parents' willingness to allow their child to use a rideshare vehicle alone, some key differences emerged. First, when looking at annual mileage, relative to respondents who estimated that they had driven $<5000 \mathrm{~km}$ in the previous year, respondents estimating that they had driven $>15,001 \mathrm{~km}$ had 1.9 times higher odds of being willing to allow their child to use a rideshare vehicle unaccompanied. Second, when looking at the DBQ violation scores, for every one score increase in violations, respondents' willingness to allow their to use a rideshare vehicle unaccompanied increased significantly by $33 \%$. Comparatively, considering unique patterns that predict willingness to allow a child to use an automated vehicle unaccompanied, again key differences emerged. First, when looking at education, relative to respondents with a primary or high school level of education, respondents with an undergraduate or postgraduate degree had 1.840 higher odds of being willing to allow their child to use an automated vehicle alone. Second, when looking at TRI innovation scores, for every one score increase in respondents' rating of technology as innovative, respondents' willingness to allow their child to use an automated vehicle alone increased by $11 \%$.

The findings from this study indicate significant levels of trepidation from parents in relation to their willingness to allow their unaccompanied child to use a rideshare or automated vehicle. While these transportation modes are in many ways distinctly different, they both provide a hypothetical means for parents to allow their child(ren) to travel without parental supervision. Consequently, they both provide very realistic freedoms for both children and parents when these transportations become available. This highlights a need for regulators to develop clear rules and requirements for rideshare companies, and ultimately automated vehicles, to ensure that the safety of children is maintained. For example, the finding that parents who had higher requirements for route control and assurance features in vehicles had lower levels of willingness to let their child travel unaccompanied in rideshare vehicles and automated vehicles suggests that effort should be put into specifying minimum standards to ensure children's safety, and to providing parents with the opportunity to monitor their child's movements. Indeed, Koppel et al. [14] found that, for some parents, having technology to monitor their children when travelling in an automated vehicle may have an impact on their willingness to use this transportation method for their unaccompanied child.

Rideshare vehicle companies could also invest in providing dedicated services for transporting unaccompanied children. As highlighted by Bartel et al. [7], some rideshare drivers can feel pressured to transport children who are not in appropriate booster seats. A dedicated service that has drivers who: (1) are willing to transport children, (2) have undergone background checks, and (3) are trained to transport children safely, may help to allay both parents' and drivers' concerns. Services dedicated to transporting children may also be beneficial in relation to automated vehicles in the future. Any efforts put into making emerging and future travel modes more appealing to parents has the potential for these transportation modes to be utilised more widely.

Several limitations to the current study must be noted. First, a self-report online survey was used. Self-report data may be subject to concerns surrounding accuracy for several reasons. In using a self-report survey, there is no guarantee that respondents were truthful in providing their responses [45]. There is also a risk that respondents rushed through the survey without giving any real consideration to their responses. Rushing through the survey may have also increased the risk for errors. Second, the survey was completed by individuals on a voluntary basis. There is a risk that this introduced bias into the study. This could have occurred through several different ways. The respondents who participated may have been those who have concerns about their children travelling unaccompanied in a rideshare or automated vehicle and wanted to share these concerns. Alternatively, the respondents who participated in this study may have a particular interest 
in the topic, or have higher levels of knowledge on the topic, which would have influenced the responses provided. Third, this study only includes data from residents in Australia. It is possible that the culture of transportation in Australia may have influenced the results. Thus, generalisability of the results to other jurisdictions should be made with caution but points to an area for future research. Examining whether the same patterns hold true in other jurisdictions could enhance our understandings of parents' willingness to use emerging and future travel modes to transport unaccompanied children. Finally, while this study explored factors that may influence parents' willingness to transport children in automated vehicles unaccompanied, it is important to recognise that this is currently based on speculation. We do not yet have full understanding of the way in which automated vehicles will impact our day-to-day lives. As knowledge and understanding of this future transportation mode develops, it is likely that attitudes towards and acceptance of technological advances will also evolve. Indeed, in this study, only a small amount of data was collected that enabled us to understand the level of knowledge that the respondents have on automated vehicles. Future research would benefit from collecting more in-depth data on knowledge of automated vehicles, in order to more fully understand whether their level of knowledge influences their willingness to use automated vehicles to transport their unaccompanied children.

\section{Conclusions}

Emerging and future transport modes (i.e., rideshare vehicles and automated vehicles) have the potential to change how parents choose to transport their children. The factors that were highlighted in this study can be used as a platform to develop clear regulations for how these services may operate to transport children safety. Ultimately, this may help to increase parents' confidence in the use of technologies to transport their children, making rideshare and automated vehicles a favourable, accessible, and sustainable transport solution.

Author Contributions: S.K.: Conceptualisation, Methodology, Ethics application, Formal analysis, Writing-original draft preparation, Writing—review and editing, Project administration; H.M.: Writing_original draft preparation, Writing_-review and editing; S.P.: Writing—original draft preparation, Writing - review and editing; X.Z.: Formal analysis, Writing—original draft preparation, Writing-review and editing; D.B.L.: Writing-original draft preparation, Writing-review and editing. All authors have read and agreed to the published version of the manuscript.

Funding: No external funding was received for this study.

Institutional Review Board Statement: The Monash University Human Research Ethics Committee approved this study (MUHREC, ID 25721, Approved 29 July 2020).

Informed Consent Statement: Informed consent was obtained from all respondents who completed the online survey.

Data Availability Statement: The data presented in this article are available from the corresponding author on reasonable request.

Conflicts of Interest: The authors have no conflict to declare. 


\section{Appendix A}

Table A1. CFA results: Rideshare.

\begin{tabular}{|c|c|c|c|c|c|}
\hline Construct & Item & Loadings & Cronbach's Alpha & CR & AVE \\
\hline \multirow{7}{*}{ Assurance } & AS2 & 0.744 & \multirow{7}{*}{0.909} & \multirow{7}{*}{0.928} & \multirow{7}{*}{0.647} \\
\hline & AS3 & 0.763 & & & \\
\hline & AS4 & 0.772 & & & \\
\hline & AS5 & 0.840 & & & \\
\hline & AS6 & 0.820 & & & \\
\hline & AS7 & 0.855 & & & \\
\hline & AS8 & 0.829 & & & \\
\hline \multirow{2}{*}{ Aggressive violations } & AV1 & 0.910 & \multirow{2}{*}{0.803} & \multirow{2}{*}{0.91} & \multirow{2}{*}{0.835} \\
\hline & AV2 & 0.918 & & & \\
\hline \multirow{4}{*}{ Comfort } & $\mathrm{C} 1$ & 0.889 & \multirow{4}{*}{0.906} & \multirow{4}{*}{0.929} & \multirow{4}{*}{0.765} \\
\hline & $\mathrm{C} 2$ & 0.889 & & & \\
\hline & $\mathrm{C} 3$ & 0.870 & & & \\
\hline & $\mathrm{C} 4$ & 0.850 & & & \\
\hline Discomfort & DIS2 & 1 & 1 & 1 & 1 \\
\hline \multirow{4}{*}{ Errors } & E10 & 0.923 & \multirow{4}{*}{0.940} & \multirow{4}{*}{0.957} & \multirow{4}{*}{0.848} \\
\hline & E6 & 0.902 & & & \\
\hline & E7 & 0.934 & & & \\
\hline & E8 & 0.925 & & & \\
\hline \multirow{4}{*}{ Innovativeness } & INN1 & 0.877 & \multirow{4}{*}{0.884} & \multirow{4}{*}{0.92} & \multirow{4}{*}{0.742} \\
\hline & INN2 & 0.884 & & & \\
\hline & INN3 & 0.797 & & & \\
\hline & INN4 & 0.884 & & & \\
\hline \multirow{2}{*}{ Insecurity } & INS2 & 0.788 & \multirow{2}{*}{0.779} & \multirow{2}{*}{0.88} & \multirow{2}{*}{0.788} \\
\hline & INS3 & 0.977 & & & \\
\hline I apcos & L1 & 0.907 & > 710 & 0.000 & ( \\
\hline Lapses & L5 & 0.881 & 0.149 & 0.808 & 0.199 \\
\hline & OPT1 & 0.885 & & & \\
\hline Ontimism & OPT2 & 0.866 & 0001 & 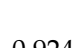 & (2752 \\
\hline Optimism & OPT3 & 0.853 & 0.891 & 0.924 & 0.752 \\
\hline & OPT4 & 0.864 & & & \\
\hline & $\mathrm{RC} 1$ & 0.802 & & & \\
\hline & $\mathrm{RC} 2$ & 0.890 & קס0 & 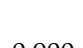 & \\
\hline Route control & $\mathrm{RC} 3$ & 0.889 & 0.852 & 0.900 & 0.694 \\
\hline & RC4 & 0.742 & & & \\
\hline & S1 & 0.858 & & & \\
\hline & S2 & 0.853 & & & \\
\hline$C_{0} f_{1}$ & S3 & 0.844 & 0011 & דת & $0<\Omega s$ \\
\hline Safety & S4 & 0.837 & 0.913 & 0.932 & 0.696 \\
\hline & S5 & 0.848 & & & \\
\hline & S7 & 0.764 & & & \\
\hline & V6 & 0.919 & & & \\
\hline Violations & V7 & 0.920 & 0.907 & 0.942 & 0.843 \\
\hline & V8 & 0.917 & & & \\
\hline
\end{tabular}


Table A2. Fornell-Larcker Criterion results: Rideshare.

\begin{tabular}{|c|c|c|c|c|c|c|c|c|c|c|c|c|}
\hline & $\begin{array}{c}\text { Aggressive } \\
\text { Violations }\end{array}$ & Assurance & Comfort & Discomfort & Errors & Innovativeness & Insecurity & Lapses & Optimism & $\begin{array}{c}\text { Route } \\
\text { Control }\end{array}$ & Safety & Violations \\
\hline $\begin{array}{c}\text { Aggressive } \\
\text { violations }\end{array}$ & 0.914 & & & & & & & & & & & \\
\hline Assurance & -0.154 & 0.804 & & & & & & & & & & \\
\hline Comfort & 0.053 & 0.564 & 0.874 & & & & & & & & & \\
\hline Discomfort & -0.147 & -0.114 & -0.233 & 1.000 & & & & & & & & \\
\hline Errors & 0.875 & -0.147 & 0.081 & -0.212 & 0.921 & & & & & & & \\
\hline Innovativeness & 0.166 & -0.056 & 0.130 & -0.142 & 0.180 & 0.861 & & & & & & \\
\hline Insecurity & -0.023 & -0.119 & 0.004 & 0.295 & -0.049 & 0.069 & 0.888 & & & & & \\
\hline Lapses & 0.765 & -0.118 & -0.013 & -0.166 & 0.799 & 0.118 & -0.090 & 0.894 & & & & \\
\hline Optimism & -0.032 & 0.061 & 0.060 & -0.079 & 0.008 & 0.468 & 0.035 & -0.010 & 0.867 & & & \\
\hline Route control & -0.243 & 0.731 & 0.359 & -0.041 & -0.236 & -0.045 & -0.131 & -0.137 & 0.131 & 0.833 & & \\
\hline Safety & -0.318 & 0.704 & 0.276 & 0.018 & -0.316 & -0.173 & -0.152 & -0.218 & 0.050 & 0.733 & 0.835 & \\
\hline
\end{tabular}


Table A3. CFA results: Automated vehicle.

\begin{tabular}{|c|c|c|c|c|c|}
\hline Construct & Item & Loadings & Cronbach's Alpha & CR & AVE \\
\hline \multirow{7}{*}{ Assurance } & AS2 & 0.810 & \multirow{7}{*}{0.932} & \multirow{7}{*}{0.945} & \multirow{7}{*}{0.712} \\
\hline & AS3 & 0.809 & & & \\
\hline & AS4 & 0.812 & & & \\
\hline & AS5 & 0.872 & & & \\
\hline & AS6 & 0.843 & & & \\
\hline & AS7 & 0.886 & & & \\
\hline & AS8 & 0.871 & & & \\
\hline \multirow{2}{*}{ Aggressive violations } & AV1 & 0.896 & \multirow{2}{*}{0.803} & \multirow{2}{*}{0.910} & \multirow{2}{*}{0.834} \\
\hline & AV2 & 0.930 & & & \\
\hline \multirow{4}{*}{ Comfort } & $\mathrm{C} 1$ & 0.870 & \multirow{4}{*}{0.904} & \multirow{4}{*}{0.932} & \multirow{4}{*}{0.775} \\
\hline & $\mathrm{C} 2$ & 0.891 & & & \\
\hline & $\mathrm{C} 3$ & 0.903 & & & \\
\hline & $\mathrm{C} 4$ & 0.855 & & & \\
\hline Discomfort & DIS2 & 1.000 & 1.000 & 1.000 & 1.000 \\
\hline \multirow{4}{*}{ Errors } & E10 & 0.928 & \multirow{4}{*}{0.940} & \multirow{4}{*}{0.957} & \multirow{4}{*}{0.848} \\
\hline & E6 & 0.904 & & & \\
\hline & E7 & 0.927 & & & \\
\hline & E8 & 0.924 & & & \\
\hline \multirow{4}{*}{ Innovativeness } & INN1 & 0.876 & \multirow{4}{*}{0.884} & \multirow{4}{*}{0.920} & \multirow{4}{*}{0.743} \\
\hline & INN2 & 0.877 & & & \\
\hline & INN3 & 0.814 & & & \\
\hline & INN4 & 0.880 & & & \\
\hline \multirow{2}{*}{ Insecurity } & INS2 & 0.900 & \multirow{2}{*}{0.779} & \multirow{2}{*}{0.901} & \multirow{2}{*}{0.819} \\
\hline & INS3 & 0.910 & & & \\
\hline Jances & L1 & 0.893 & 7 710 & 0880 & 0800 \\
\hline 2ароео & L5 & 0.895 & 0.749 & 0.009 & 0.000 \\
\hline & OPT1 & 0.876 & & & \\
\hline Ontimism & OPT2 & 0.891 & & & \\
\hline Uptimism & OPT3 & 0.868 & 0.891 & 0.924 & 0.753 \\
\hline & OPT4 & 0.835 & & & \\
\hline & $\mathrm{RC} 1$ & 0.795 & & & \\
\hline & $\mathrm{RC} 2$ & 0.878 & 0.004 & 0017 & דבר \\
\hline Route control & RC3 & 0.888 & 0.884 & 0.917 & 0.735 \\
\hline & $\mathrm{RC} 4$ & 0.865 & & & \\
\hline & S1 & 0.870 & & & \\
\hline & S2 & 0.858 & & & \\
\hline Safoty & S3 & 0.874 & (2007 & 0011 & 0726 \\
\hline Salety & S4 & 0.825 & 0.925 & 0.941 & 0.726 \\
\hline & S5 & 0.856 & & & \\
\hline & S7 & 0.828 & & & \\
\hline & V6 & 0.921 & & & \\
\hline Violations & V7 & 0.916 & 0.907 & 0.942 & 0.843 \\
\hline & V8 & 0.917 & & & \\
\hline
\end{tabular}


Table A4. Fornell-Larcker Criterion results: Automated vehicle.

\begin{tabular}{|c|c|c|c|c|c|c|c|c|c|c|c|c|}
\hline & $\begin{array}{c}\text { Aggressive } \\
\text { Violations }\end{array}$ & Assurance & Comfort & Discomfort & Errors & Innovativeness & Insecurity & Lapses & Optimism & $\begin{array}{c}\text { Route } \\
\text { Control }\end{array}$ & Safety & Violations \\
\hline $\begin{array}{c}\text { Aggressive } \\
\text { violations }\end{array}$ & 0.913 & & & & & & & & & & & \\
\hline Assurance & -0.207 & 0.844 & & & & & & & & & & \\
\hline Comfort & -0.045 & 0.652 & 0.880 & & & & & & & & & \\
\hline Discomfort & -0.148 & -0.048 & -0.146 & 1.000 & & & & & & & & \\
\hline Errors & 0.876 & -0.215 & -0.038 & -0.212 & 0.921 & & & & & & & \\
\hline Innovativeness & 0.165 & -0.093 & 0.049 & -0.138 & 0.179 & 0.862 & & & & & & \\
\hline Insecurity & -0.033 & -0.097 & -0.075 & 0.315 & -0.053 & 0.046 & 0.905 & & & & & \\
\hline Lapses & 0.769 & -0.155 & -0.050 & -0.167 & 0.803 & 0.118 & -0.097 & 0.894 & & & & \\
\hline Optimism & -0.033 & 0.067 & 0.031 & -0.084 & 0.008 & 0.464 & 0.029 & -0.008 & 0.868 & & & \\
\hline Route control & -0.278 & 0.762 & 0.432 & 0.004 & -0.276 & -0.126 & -0.125 & -0.192 & 0.073 & 0.857 & & \\
\hline Safety & -0.351 & 0.756 & 0.415 & 0.032 & -0.361 & -0.139 & -0.165 & -0.233 & 0.075 & 0.827 & 0.852 & \\
\hline
\end{tabular}




\section{References}

1. United Nations. Accessible, Affordable, Environmentally Friendly Systems Vital for Sustainable Transport, Secretary-General Stresses at Opening of Global Conference. 2016. Available online: https:/ /www.un.org/press/en/2016/sgsm18303.doc.htm (accessed on 25 October 2021).

2. Koppel, S.; Octavio, J.J.; Bohman, K.; Logan, D.; Raphael, W.; Jimenez, L.Q.; Lopez-Valdes, F. Seating configuration and position preferences in fully automated vehicles. Traffic Inj. Prev. 2019, 20 (Suppl. 2), S103-S109. [CrossRef] [PubMed]

3. Koppel, S.; Peiris, S.; Aburumman, M.; Wong, C.W.R.; Owens, J.M.; Womack, K.N. What Are the Restraint Practices, Preferences, and Experiences When Australian Parents Travel with Their Children in a Rideshare Vehicle? Int. J. Environ. Res. Public Health 2021, 18, 8928. [CrossRef] [PubMed]

4. Ehsani, J.P.; Michael, J.P.; Gielen, A. Rideshare use amongst parents and their children. Inj. Epidemiol. 2021, 8, 9. [CrossRef] [PubMed]

5. Owens, J.M.; Womack, K.N.; Barowski, L. Factors Surrounding Child Seat Usage in Rideshare Services. Safe-D National UTC Virginia Tech Transportation Institute, Texas A\&M Transportation Institute. 2019. Available online: https://vtechworks.lib.vt. edu/bitstream/handle/10919/95172/01005_Final\%20Research\%20Report_Final.pdf?sequence=1\&isAllowed=y (accessed on 9 November 2021).

6. Savage, M.F.; Kendi, S.; Macy, M.L. Ride-share use and child passenger safety behaviors: An online survey of parents. Acad. Pediatr. 2021, 21, 1363-1371. [CrossRef]

7. Bartel, E.; MacEachen, E.; Reid-Musson, E.; Meyer, S.B.; Saunders, R.; Migelow, P.; Kosny, A.; Varatharajan, S. Stressful by design: Exploring health risk of ride-share work. J. Transp. Health 2019, 14, 100571. [CrossRef]

8. Lee, Y.C.; Mirman, J.H. Parents' perspectives on using autonomous vehicles to enhance children's mobility. Transp. Res. Part C Emerg. Technol. 2018, 96, 415-431. [CrossRef]

9. Lee, C.; Rahafrootz, M.; Lee, O.K. What are the concerns of using a ride-sharing service? An investigation of Uber. In Proceedings of the Twenty-third Americas Conference on Information Systems, Boston, MA, USA, 10-12 August 2017.

10. Bayne, A.; Siegfried, A.; Beck, L.F.; Freund, K. Barriers and facilitators of older adults' use of ride share services. J. Transp. Health 2021, 21, 101055. [CrossRef]

11. Lee, Y.C.; Hand, S.H.; Lilly, H. Are parents ready to use autonomous vehicles to transport children? Concerns and safety features. J. Safety Res. 2020, 72, 287-297. [CrossRef]

12. Jing, P.; Du, L.; Chen, Y.; Shi, Y.; Zhan, F.; Cie, J. Factors that influence parents' intentions of using autonomous vehicles to transport children to and from school. Accid. Anal. Prev. 2021, 152, 105991. [CrossRef]

13. Tremoulet, P.D.; Seacrist, T.; McIntosh, C.W.; Loeb, H.; DiPietro, A.; Tushak, S. Transporting children in autonomous vehicles: An exploratory study. Hum. Factors 2020, 62, 278-287. [CrossRef]

14. Koppel, S.; Lee, Y.-C.; Mirman, J.H.; Peiris, S.; Tremoulet, P. Key factors associated with Australian parents' willingness to use an automated vehicle to transport their unaccompanied children. Transp. Res. Part F Traffic Psychol. Behav. 2021, 78, 137-152. [CrossRef]

15. Bureau of Infrastructure, Transport and Regional Economics (BITRE). Road Trauma Australia 2020 Statistical Summary; BITRE: Canberra, Australia, 2021. Available online: https://www.bitre.gov.au/sites/default/files/documents/road_trauma_australia_ 2020_statistical_summary.pdf (accessed on 10 November 2021).

16. Anderson, J.M.; Kalra, N.; Stanley, K.; Sorensen, P.; Samaras, C.; Oluwatala, O.A. Autonomous Vehicle Technology: A Guide for Policymakers; RAND Corporation: Santa Monica, CA, USA, 2016. Available online: https://www.rand.org/pubs/research_ reports/RR443-2.html (accessed on 10 November 2021).

17. Pudāne, B.; Rataj, M.; Molin, E.; Mouter, N.; van Cranenburgh, S.; Chorus, C.G. How will automated vehicles shape users' daily activities? Insights from focus groups with commuters in the Netherlands. Transp. Res. Part D Transp. Environ. 2019, 71, 222-235. [CrossRef]

18. Hardman, S.; Berliner, R.; Tal, G. Who will be the early adopters of automated vehicles? Insights from a survey of electric vehicle owners in the United States. Transp. Res. Part D Transp. Environ. 2019, 71, 248-264. [CrossRef]

19. Szénási, S. Analysis of historical road accident data supporting autonomous vehicle control strategies. PeerJ Comput. Sci. 2021, 7, e399. [CrossRef]

20. Bansal, P.; Kockelman, K.M. Are we ready to embrace connected and self-driving vehicles? A case study of Texans. Transportation 2018, 45, 641-675. [CrossRef]

21. Sperling, D.; Pike, S.; Chase, R. Will the transportation revolutions improve our lives-or make them worse? In Three Revolutions: Steering Automated, Shared and Electric Vehicles to a Better Future; Sperling, D., Ed.; Island Press: Washington, DC, USA, 2018. Available online: https:/ /link.springer.com/content/pdf/10.5822\%2F978-1-61091-906-7_1.pdf (accessed on 14 November 2021).

22. Furuhata, M.; Dessouky, M.; Ordóñez, F.; Brunet, M.E.; Wang, X.; Koeing, S. Ridesharing: The state-of-the-art and future directions. Transp. Res. Part B Methodol. 2013, 57, 28-46. [CrossRef]

23. Blyth, P.L. Of cyberliberation and forbidden fornication: Hidden transcripts of autonomous mobility in Finland. Transp. Res. Part D Transp. Environ. 2019, 71, 236-247. [CrossRef]

24. Freund, K.; Bayne, A.; Beck, L.; Siegfried, A.; Warren, J.; Nadel, T.; Natarajan, A. Characteristics of ride share services for older adults in the United States. J. Safety Res. 2020, 72, 9-19. [CrossRef] [PubMed] 
25. Axsen, J.; Sovacool, B.K. The roles of users in electric, shared and automated mobility transitions. Transp. Res. Part D Transp. Environ. 2019, 71, 1-21. [CrossRef]

26. Spurlock, C.A.; Sears, J.; Wong-Parodi, G.; Walker, V.; Jin, L.; Taylor, M.; Duvall, A.; Gopal, A.; Todd, A. Describing the users: Understanding adoption of and interest in shared, electrified, and automated transportation in the San Francisco Bay Area. Transp. Res. Part D Transp. Environ. 2019, 71, 283-301. [CrossRef]

27. Williams, E.; Das, V.; Fisher, A. Assessing the Sustainability Implications of Autonomous Vehicles: Recommendations for Research Community Practice. Sustainability 2020, 12, 1902. [CrossRef]

28. Zhang, Y.; Zhang, Y. Examining the relationship between household vehicle ownership and ridesharing behaviors in the United States. Sustainability 2018, 10, 2720. [CrossRef]

29. Greenblatt, J.B.; Shaheen, S. Automated vehicles, on-demand mobility, and environmental impacts. Curr. Sustain. Energy Rep. 2015, 2, 74-81. [CrossRef]

30. Ward, J.W.; Michalek, J.J.; Azevedo, I.L.; Samaras, C.; Ferreira, P. Effects of on-demand ridesourcing on vehicle ownership, fuel consumption, vehicle miles travelled, and emissions per capita in U.S. States. Transp. Res. Part C Emerg. Technol. 2019, 108, 289-301. [CrossRef]

31. Jin, S.T.; Kong, H.; Wu, R.; Sui, D.Z. Ridesourcing, the sharing economy, and the future of cities. Cities 2018, 76, 96-104. [CrossRef]

32. Polydoropoulou, A.; Tsouros, I.; Thomopoulos, N.; Pronello, C.; Elvarsson, A.; Sigpórsson, H.; Dadashzadeh, N.; Stojmenova, K.; Sodnik, J.; Neophytou, S.; et al. Who is willing to share their AV? Insights about gender differences among seven countries. Sustainability 2021, 13, 4769. [CrossRef]

33. Massar, M.; Reza, I.; Rahman, S.M.; Abdullah, S.M.H.; Jamal, A.; Al-Ismail, F.S. Impacts of autonomous vehicles on greenhouse gas emissions-Positive or Negative? Int. J. Environ. Res. Public Health 2021, 18, 5567. [CrossRef]

34. Bureau of Infrastructure, Transport and Regional Economics (BITRE). Traffic and Congestion Cost Trends for Australian Capital Cities; Information Sheet 74; BITRE: Canberra, Australia, 2015. Available online: https://www.bitre.gov.au/sites/default/files/is_074. pdf (accessed on 10 November 2021).

35. Harb, M.; Xiao, Y.; Circella, G.; Mokhtarian, P.L.; Walker, J.L. Projecting travellers into a world of self-driving vehicles: Estimating travel behaviour implications via a naturalistic experiment. Transportation 2018, 45, 1671-1685. [CrossRef]

36. Reason, J.; Manstead, A.; Stradling, S.; Baxter, J.; Campbell, K. Errors and violations on the roads: A real distinction? Ergonomics 1990, 33, 1315-1332. [CrossRef]

37. Lawton, R.; Parker, D.; Stradling, S.G.; Manstead, A.S. Predicting road traffic accidents: The role of social deviance and violations. Br. J. Psychol. 1997, 88, 249-262. [CrossRef]

38. Stephens, A.; Fitzharris, M. Validation of the driver behaviour questionnaire in a representative sample of drivers in Australia. Accid. Anal. Prev. 2016, 86, 186-198. [CrossRef] [PubMed]

39. Parker, D.; Reason, J.T.; Manstead, A.S.; Stradling, S.G. Driving errors, driving violations and accident involvement. Ergonomics 1995, 38, 1036-1048. [CrossRef] [PubMed]

40. Parasuraman, A.; Colby, C.L. An updated and streamlined technology readiness index: TRI 2.0. J. Serv. Res. 2015, 18, 59-74. [CrossRef]

41. Hair, J.F.; Hult, G.T.M.; Ringle, C.M.; Sarstedt, M. A Primer on Partial Least Squares Structural Equation Modeling (PLS-SEM), 2nd ed.; SAGE: Los Angeles, CA, USA, 2017. Available online: https://au.sagepub.com/en-gb/oce/a-primer-on-partial-least-squaresstructural-equation-modeling-pls-sem/book244583 (accessed on 20 October 2021).

42. Hair, J.F.; Risher, J.J.; Sarstedt, M.; Ringle, C.M. When to use and how to report the results of PLS-SEM. Eur. Bus. Rev. 2019, 31, 2-24. [CrossRef]

43. Hosmer, D.W.; Lemeshow, S. Applied Logistic Regression, 2nd ed.; John Wiley \& Sons: New York, NY, USA, 2000.

44. Hosmer, D.W.; Lemeshow, S.; Sturdivant, R.X. Applied Logistic Regression, 3rd ed.; John Wiley \& Sons: New York, NY, USA, 2013.

45. Adams, S.A.; Matthews, C.E.; Ebbeling, C.B.; Moore, C.G.; Cunningham, J.E.; Fulton, J.; Hebert, J.R. The effect of social desirability and social approval on self-reports of physical activity. Am. J. Epidemiol. 2005, 161, 389-398. [CrossRef] [PubMed] 